\title{
Encounters between Physiotherapists and Clients with Suicidal Thoughts and Behaviours: A Narrative Literature Review
}

Ryan L. McGrath BPhysio(Hons)

PhD student, School of Community Health, Charles Sturt University, Albury, New South Wales, Australia

Jasmine B. MacDonald PhD, BA/BSW(Hons)

Lecturer, Discipline of Psychology, RMIT University, Melbourne, Victoria, Australia; Adjunct Lecturer, School of Psychology, Charles Sturt University, Wagga Wagga, New South Wales, Australia

Sarah Verdon PhD, BHIthSc(SpPath)(Hons)

Senior Lecturer in Speech and Language Pathology/Research Fellow, School of Community Health, Charles Sturt University, Albury, New South Wales, Australia

Tracey Parnell PhD, MOT, BAppSc(Occ Th)

Discipline Lead, Lecturer in Occupational Therapy, School of Community Health, Charles Sturt University, Albury, New South Wales, Australia

Megan Smith PhD, MAppSc(Cardiopulmphysio), BAppSc(Physio)

Executive Dean, Faculty of Science, Charles Sturt University, Wagga Wagga, New South Wales, Australia

\section{ABSTRACT}

This narrative review examined the literature relevant to encounters between physiotherapists and clients with suicidal thoughts and behaviours (STBs). The review was conducted in response to a growing international movement to make suicide prevention everyone's business. The Framework for Suicide Risk Assessment and Management for NSW Health Staff (New South Wales Department of Health, 2004) informed the review as it requires all New South Wales Department of Health practitioners, including physiotherapists, to be able to assess and manage clients with STBs. The review identified 23 peer-reviewed articles and four non-peer-reviewed articles that mentioned encounters between physiotherapists and clients with STBs. The results suggest that physiotherapists may encounter clients with STBs given the conditions they manage, the increased risk of suicide associated with these conditions, and the pattern of contact between health professionals and clients with STBs. Future research is required to explore the prevalence of STBs among physiotherapy clients, the experiences of physiotherapists who have identified clients with STBs, and whether physiotherapists are adequately trained and competent in suicide risk assessment.

McGrath, R. L., MacDonald, J. B., Verdon, S., Parnell, T., \& Smith, M. (2021). Encounters between physiotherapists and clients with suicidal thoughts and behaviours: A narrative literature review. New Zealand Journal of Physiotherapy, 49(2), 70-81. https://doi.org/10.15619/NZJP/49.2.03

Key Words: Self-Injurious Behaviour, Suicide, Physical Therapy Specialty, Physiotherapy

\section{INTRODUCTION}

The current review was conducted in response to a growing international movement to make suicide prevention everyone's business (World Health Organization, 2010). More specifically, the review was inspired by the Framework for Suicide Risk Assessment and Management for NSW Health Staff (New South Wales Department of Health [NSW Health], 2004). NSW Health (2019) is the largest public healthcare system in Australia. The Framework for Suicide Risk Assessment and Management for NSW Health Staff (NSW Health, 2004) is of significance as it requires all NSW health practitioners, including physiotherapists, to be able to conduct a preliminary suicide risk assessment (SRA). A preliminary SRA involves a brief psychiatric assessment and an assessment of suicide risk; these assessments require practitioners to directly ask the client about their suicidal thoughts (NSW Health, 2004). According to the framework, all NSW Health practitioners must be provided with training in SRA that is "consistent with their experience and exposure to people at risk of suicide" (NSW Health, 2004, p. 6).

People most commonly self-refer to physiotherapists for the diagnosis and treatment of conditions that cause pain and loss of function/mobility (McRae \& Hancock, 2017). According to the interpersonal theory of suicide (Joiner, 2005) and the three-step theory of suicide (Klonsky \& May, 2015) the factors involved in the pathway to suicide are pain, hopelessness, and social disconnectedness (which is a combination of low belongingness and high burdensomeness). Pain and loss of physical function can lead to suicide via various pathways, such as increasing feelings of burdensomeness (Conejero et al., 2018; Dempsey et al., 2012; Eisenberger, 2012; LeRoy et al., 2018). These models highlight the importance of investigating the relationship between poor physical health, physical pain, and suicidal thoughts and behaviours (STBs). By extension, these models also suggest that physiotherapists may come into contact 
with people with STBs. For this review, STBs were defined as a continuum ranging from suicidal ideation to death by suicide (Littlewood et al., 2017).

Poor physical health may not just correlate with STBS, but also be a primary motivator of STBs (Fegg et al., 2016). Fegg et al. analysed the suicide, medical and police notes of 1,069 suicide deaths in Germany between 2009 and 2011. The authors concluded that $18.9 \%$ of individuals completed suicide due to physical reasons. Clapperton, Newstead, et al. (2020) found that for people with stable depression, poor physical health served as a stressor, exacerbating the person's depressive symptoms and STBS, which then resulted in suicide. It appears that there are two groups of people with physical health issues at risk of completing suicide: (a) people with diagnosed mental illness and physical health problems, which act as a stressor; and (b) people with physical health problems and no diagnosed mental illness (Clapperton, Bugeja, et al., 2020). People with physical health problems and no diagnosed mental illness tend to be older and less likely to experience interpersonal, personal and situational stressors than other groups who completed suicide (Clapperton, Bugeja, et al., 2020). Incomplete suicides may also result in life-changing physical conditions (Papadakis et al., 2014). For example, incomplete high fall suicides may result in paraplegia and brain injury (Papadakis et al., 2014; Papadakis et al., 2020). Physical injuries sustained during suicide may also develop into chronic pain conditions (Hiraiwa et al., 2014). Overall, there is a substantial body of convergent evidence suggesting that poor physical health is both (a) a risk factor for suicide in people regardless of mental illness diagnosis and (b) a sequela of incomplete suicide.

The three-step theory of suicide posits that the first step in the development of suicidal ideation is pain and that this pain is not limited to psychological pain (Klonsky \& May, 2015). Physical pain can directly contribute to suicidal ideation and indirectly through its relationship with psychological pain (Pachkowski et al., 2020). The association between physical pain and suicide is theoretically mediated by "helplessness/hopelessness about the ability to cope and about the chances of future relief from pain" (Tang \& Crane, 2006, p. 582). A meta-analysis of 31 studies found that people with physical pain were more likely than those not experiencing physical pain to have current and lifetime suicidal ideation, suicidal plans, incomplete suicide, and complete suicide (Calati et al., 2015). Fishbain et al. (2009) is the only study to have compared the prevalence of STBs amongst people experiencing acute and chronic pain; they found that people with acute or chronic pain are both at an elevated risk of suicide when compared to pain-free controls.

The relationship between physical pain and the development of STBs may impact physiotherapy practice given that a high proportion of those seeking physiotherapy services experience pain (McRae \& Hancock, 2017). A meta-synthesis of 49 articles investigating the effect of back pain on people's lives found that feelings of depression and hopelessness were common among people with back pain, and there was evidence of suicidal ideation among some participants in these studies (Froud et al., 2014). Petrosky et al. (2018) examined a random sample of 200 people who completed suicide, had chronic pain, and who had left a suicide note. Of the 95 cases where the content of the suicide note was available to be studied, Petrosky et al. found that pain was a motivator in the individual's suicide in 64 cases (67.5\%).

Due to the relationship between suicide and poor physical health and pain, it was expected that physiotherapists would encounter clients with STBs (Calati et al., 2015; Fässberg et al., 2016). The aim of this review was to synthesise the existing literature which mentions contact between physiotherapists and clients with STBS, and provides insight into the experiences of physiotherapists with clients with STBs. The research questions were:

1. What evidence is there for contact between physiotherapists and clients with STBS?

2. What is known about the experiences of physiotherapists with clients with STBs?

The intention of this review was to (a) highlight the significance of this practice issue for physiotherapists, (b) provide a foundation for future research, and (c) inform health policy.

\section{METHODS}

A preliminary scoping search of the literature revealed: (a) a paucity of empirical studies which specifically investigated contact between physiotherapists and clients with STBs, and (b) that the focus and methods of the existing literature appeared diverse and piecemeal in nature. Based on the preliminary search, a narrative review approach informed by an interpretivist theoretical framework was chosen. While a systematic review approach was considered, the narrative review approach is "better suited to addressing a topic in wider ways" (Baethge et al., 2019, p. 2) and offers "greater flexibility in searching and synthesizing articles" (Paré \& Kitsiou, 2017, p. 172). This flexibility in searching and synthesising articles was essential as multiple types of articles, including commentaries, editorials, and research studies, would all eventually be included within the review. However, in line with recent trends (Ferrari, 2015; Paré \& Kitsiou, 2017), some of the methodological features of systematic reviews were adopted to enhance the transparency of this narrative review (Figure 1). While the method described below resembles that of a systematic review, it is important to emphasise that the review was conceptualised as a narrative review, which meant that any article that the research team believed would provide insight into the research topic would be included. This method is consistent with Paré et al. (2015), who stated that narrative reviews tend to be opportunistic and survey literature that is readily available to the researchers.

The literature search was conducted in October 2020. The search terms physiotherap*, physical therap*, and suicid* were used to find potentially relevant articles. Articles were included if (a) they were available in English; and (b) explicitly discussed or mentioned the contact between a physiotherapist and a client with STBs, or discussed the experiences of physiotherapists working with clients with STBs. The databases Ovid Medline ${ }^{8}$, CINAHL Plus with Full Text, and PEDro were selected, with 135 articles identified through the search of the literature. The full text of each article was downloaded, as encounters between physiotherapists and clients with STBs were often only briefly mentioned. 


\section{Figure 1}

Search Strategy of the Narrative Literature Review Process

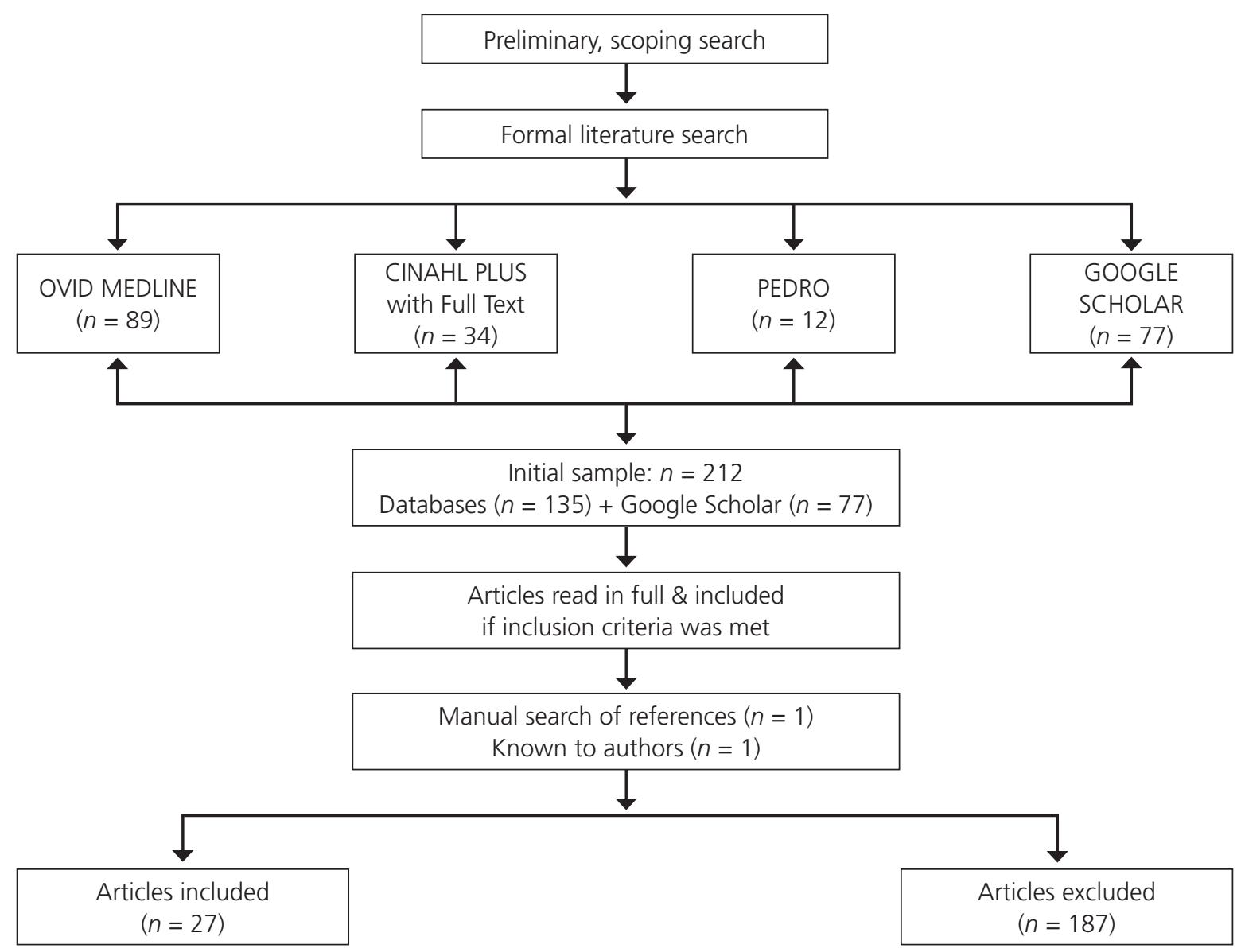

The search engine Google Scholar was also used to identify relevant articles, particularly grey literature that is not indexed by traditional databases (Haddaway et al., 2015). Although Google Scholar should not be used as a standalone resource, Haddaway et al. (2015) argues that it is a "powerful addition to other traditional search methods" (p. 1). Due to Google Scholar's limited search functionality, such as the inability to nest query terms and to recognise truncation symbols (Ortega, 2014), seven searches were performed using different combinations of keywords and inclusion criteria (i.e., keywords "in the title of the article" or "anywhere in the article"). In total, 11,232 results were returned. The number of results was significantly larger than the search of the traditional databases because Google Scholar identified any article that had the keywords "physiotherap*" or "physical therap*" in at least one of the author's affiliation or in the reference section, but not necessarily in the content of the article. Haddaway et al. noted that some reviewers opt to screen the first 50 to 100 results to manage a large number of results, as Google Scholar uses a ranking algorithm for relevance in regard to the search terms (Rovira et al., 2019). For this review, screening articles was not possible as it was often necessary to read each identified article in full to find any mention of contact between physiotherapists and clients with STBs. As a compromise, the first 25 results of each of the searches were downloaded and read in full. In total, 77 articles were downloaded and read in full as not all searches of Google Scholar returned 25 or more results.

The full text of the 212 articles identified (databases, $n=135$; Google Scholar, $n=77$ ) were read in their entirety so as to not miss any mention of encounters between physiotherapists and clients with STBs. The references of all 212 articles were manually screened, leading to the inclusion of one article (Agence France-Presse, 2007). One additional article known to the authors was included due to its relevance (Doesburg, 2016). The study by Doesburg was discovered through a Google Scholar search during the preliminary search phase and does not appear to be indexed by any major database.

\section{RESULTS}

Table 1 provides an overview of the 27 articles included in this review. Articles from 13 countries were identified from as early as 2003, indicating that this is a topic of international relevance; 23 articles were peer-reviewed; and case studies were the most common research design $(n=11)$. 
Table 1

Summary of Studies Describing Physiotherapists Experience of and/or Contact With Clients With Suicidal Thoughts and Behaviours

\begin{tabular}{|c|c|c|c|c|c|c|}
\hline Study & Country & $\begin{array}{l}\text { Research } \\
\text { design }\end{array}$ & Sample $(n)$ & Focus of the study & $\begin{array}{c}\text { STBs } \\
\text { described }\end{array}$ & $\begin{array}{l}\text { Connection to } \\
\text { physiotherapists }\end{array}$ \\
\hline $\begin{array}{l}\text { Edmunds and } \\
\text { Gafner (2003) }\end{array}$ & United States & Case study & $\begin{array}{l}\text { Patients who were } \\
\text { refugees ( } 2 \text { ) }\end{array}$ & $\begin{array}{l}\text { Combined } \\
\text { hypnotic ego } \\
\text { strengthening } \\
\text { and zero } \\
\text { balancing } \\
\text { treatment }\end{array}$ & $\begin{array}{l}\text { Non-fatal } \\
\text { attempt(s) }\end{array}$ & $\begin{array}{c}\text { The patient had } \\
\text { participated in } \\
\text { physiotherapy }\end{array}$ \\
\hline $\begin{array}{l}\text { Gyllensten et } \\
\text { al. (2003) }\end{array}$ & Sweden & $\begin{array}{l}\text { Qualitative } \\
\text { case study }\end{array}$ & $\begin{array}{l}\text { Patients with } \\
\text { schizophrenia (6) and } \\
\text { general psychiatric } \\
\text { outpatients (5) }\end{array}$ & $\begin{array}{l}\text { Patient experiences } \\
\text { of body } \\
\text { awareness } \\
\text { therapy in } \\
\text { psychiatric } \\
\text { physiotherapy }\end{array}$ & Ideation & $\begin{array}{l}\text { The programme } \\
\text { was led by } \\
\text { physiotherapists }\end{array}$ \\
\hline $\begin{array}{l}\text { Berg et al. } \\
(2006)\end{array}$ & Norway & Survey & Police officers $(3,272)$ & $\begin{array}{r}\text { Help-seeking } \\
\text { behaviours }\end{array}$ & Ideation & $\begin{array}{l}\text { Participant } \\
\text { contact with } \\
\text { physiotherapists } \\
\text { was assessed }\end{array}$ \\
\hline $\begin{array}{l}\text { Agence } \\
\text { France-Presse } \\
(2007)\end{array}$ & Iraq & $\begin{array}{l}\text { Newspaper } \\
\text { article } \\
\text { (not peer- } \\
\text { reviewed) }\end{array}$ & Physiotherapist (1) & $\begin{array}{l}\text { Self-immolation } \\
\text { in Iraqi Kurdish } \\
\text { women }\end{array}$ & $\begin{array}{l}\text { Non-fatal } \\
\text { attempt(s) }\end{array}$ & $\begin{array}{l}\text { Physiotherapist } \\
\text { reported that } \\
\text { patients would } \\
\text { confide in her }\end{array}$ \\
\hline $\begin{array}{l}\text { Taylor et al. } \\
(2007)\end{array}$ & Australia & Interviews & $\begin{array}{l}\text { South Australian } \\
\text { general population } \\
(5,037)\end{array}$ & $\begin{array}{l}\text { Self-reported } \\
\text { prevalence of } \\
\text { suicidal ideation } \\
\text { and associated } \\
\text { risk factors }\end{array}$ & Ideation & $\begin{array}{l}\text { Participant } \\
\text { contact with } \\
\text { physiotherapists } \\
\text { was assessed }\end{array}$ \\
\hline Berg (2011) & Norway & Case study & $\begin{array}{l}\text { Patient with Parkinson's } \\
\text { disease and comorbid } \\
\text { depression (1) }\end{array}$ & $\begin{array}{l}\text { Electroconvulsive } \\
\text { treatment }\end{array}$ & Ideation & $\begin{array}{c}\text { The patient had } \\
\text { participated in } \\
\text { physiotherapy }\end{array}$ \\
\hline Ekerholt (2011) & Norway & Interviews & $\begin{array}{l}\text { Patients who } \\
\text { underwent } \\
\text { psychomotor } \\
\text { physiotherapy (10) }\end{array}$ & $\begin{array}{l}\text { Patient experiences } \\
\text { of treatment }\end{array}$ & Ideation & $\begin{array}{c}\text { The patients had } \\
\text { participated in } \\
\text { physiotherapy }\end{array}$ \\
\hline $\begin{array}{l}\text { Malcolm and } \\
\text { Scott (2012) }\end{array}$ & Germany & $\begin{array}{r}\text { Anecdotal } \\
\text { editorial }\end{array}$ & Football player (1) & $\begin{array}{l}\text { The role of sports } \\
\text { medicine } \\
\text { practitioners } \\
\text { in the } \\
\text { assessment and } \\
\text { management of } \\
\text { STBs and mental } \\
\text { health problems }\end{array}$ & $\begin{array}{l}\text { Completed } \\
\text { suicide }\end{array}$ & $\begin{array}{l}\text { The individual was } \\
\text { reported to have a } \\
\text { close relationship } \\
\text { with the club } \\
\text { physiotherapist }\end{array}$ \\
\hline $\begin{array}{l}\text { Cheeks et al. } \\
(2014)\end{array}$ & United States & Case study & $\begin{array}{l}\text { Patient with a } \\
\text { worsening cardiac } \\
\text { condition (1) }\end{array}$ & $\begin{array}{l}\text { Clinical decision- } \\
\text { making }\end{array}$ & Ideation & $\begin{array}{l}\text { Case was managed } \\
\text { by a physiotherapist }\end{array}$ \\
\hline
\end{tabular}




\begin{tabular}{|c|c|c|c|c|c|c|}
\hline Study & Country & $\begin{array}{l}\text { Research } \\
\text { design }\end{array}$ & Sample $(n)$ & Focus of the study & $\begin{array}{c}\text { STBs } \\
\text { described }\end{array}$ & $\begin{array}{l}\text { Connection to } \\
\text { physiotherapists }\end{array}$ \\
\hline $\begin{array}{l}\text { Kowal et al. } \\
\text { (2014) }\end{array}$ & Canada & $\begin{array}{l}\text { Pre- and post- } \\
\text { treatment } \\
\text { evaluation }\end{array}$ & $\begin{array}{l}\text { Patients with chronic } \\
\text { pain }(250)\end{array}$ & $\begin{array}{l}\text { Effectiveness of an } \\
\text { interdisciplinary } \\
\text { rehabilitation } \\
\text { programme to } \\
\text { reduce suicidal } \\
\text { ideation }\end{array}$ & Ideation & $\begin{array}{l}\text { Physiotherapists } \\
\text { were part of the } \\
\text { interdisciplinary } \\
\text { management }\end{array}$ \\
\hline $\begin{array}{l}\text { Lascelles } \\
(2014)\end{array}$ & $\begin{array}{l}\text { United } \\
\text { Kingdom }\end{array}$ & $\begin{array}{l}\text { Opinion piece } \\
\text { referencing } \\
\text { unpublished } \\
\text { research } \\
\text { findings } \\
\text { (not peer- } \\
\text { reviewed) }\end{array}$ & Physiotherapists (5) & $\begin{array}{l}\text { Role and } \\
\text { training of } \\
\text { physiotherapists } \\
\text { in suicide } \\
\text { prevention }\end{array}$ & Ideation & $\begin{array}{l}\text { Participants in the } \\
\text { unpublished study }\end{array}$ \\
\hline $\begin{array}{l}\text { Marusic et al. } \\
(2014)\end{array}$ & Croatia & Case study & $\begin{array}{l}\text { Patient with bipolar } \\
\text { disorder who } \\
\text { intentionally } \\
\text { overdosed on valproic } \\
\text { acid (1) }\end{array}$ & $\begin{array}{l}\text { Neuropathy as } \\
\text { a result of } \\
\text { intentional } \\
\text { overdose }\end{array}$ & $\begin{array}{l}\text { Non-fatal } \\
\text { attempt(s) }\end{array}$ & $\begin{array}{c}\text { The patient had } \\
\text { participated in } \\
\text { physiotherapy }\end{array}$ \\
\hline $\begin{array}{l}\text { Nielsen et al. } \\
(2014)\end{array}$ & Australia & Interviews & Physiotherapists (8) & $\begin{array}{l}\text { Implementing } \\
\text { cognitive- } \\
\text { behavioural } \\
\text { interventions }\end{array}$ & $\begin{array}{l}\text { Assessing } \\
\text { suicide risk }\end{array}$ & $\begin{array}{l}\text { Participants in the } \\
\text { study }\end{array}$ \\
\hline $\begin{array}{l}\text { Shetye et al. } \\
(2014)\end{array}$ & India & Case study & $\begin{array}{l}\text { Patient with delayed } \\
\text { onset neuropathy and } \\
\text { recurrent laryngeal } \\
\text { nerve palsy secondary } \\
\text { to organophosphate } \\
\text { insecticide poisoning } \\
\text { (1) }\end{array}$ & $\begin{array}{l}\text { Role of } \\
\text { physiotherapy } \\
\text { for delayed onset } \\
\text { neuropathy }\end{array}$ & $\begin{array}{l}\text { Non-fatal } \\
\text { attempt(s) }\end{array}$ & $\begin{array}{c}\text { The patient had } \\
\text { participated in } \\
\text { physiotherapy }\end{array}$ \\
\hline $\begin{array}{l}\text { Doesburg } \\
(2016)\end{array}$ & New Zealand & $\begin{array}{l}\text { Magazine } \\
\text { article } \\
\text { (not peer- } \\
\text { reviewed) }\end{array}$ & $\begin{array}{l}\text { Physiotherapists ( } n \text { not } \\
\text { stated) }\end{array}$ & $\begin{array}{l}\text { Guidance to } \\
\text { physiotherapists } \\
\text { performing } \\
\text { suicide risk } \\
\text { assessments }\end{array}$ & $\begin{array}{l}\text { Assessing } \\
\text { suicide risk }\end{array}$ & $\begin{array}{l}\text { Physiotherapy New } \\
\text { Zealand members } \\
\text { reported contact } \\
\text { and wanted } \\
\text { guidance }\end{array}$ \\
\hline $\begin{array}{l}\text { Lo Pardo et al. } \\
(2016)\end{array}$ & Italy & Case study & $\begin{array}{l}\text { Patient with delayed } \\
\text { neuropsychiatric } \\
\text { syndrome secondary } \\
\text { to carbon monoxide } \\
\text { poisoning (1) }\end{array}$ & $\begin{array}{l}\text { Hyperbaric oxygen } \\
\text { therapy }\end{array}$ & $\begin{array}{l}\text { Non-fatal } \\
\text { attempt(s) }\end{array}$ & $\begin{array}{c}\text { The patient had } \\
\text { participated in } \\
\text { physiotherapy }\end{array}$ \\
\hline $\begin{array}{l}\text { McVey et al. } \\
(2016)\end{array}$ & $\begin{array}{l}\text { United } \\
\text { Kingdom }\end{array}$ & Forum & $\begin{array}{l}\text { Members of the general } \\
\text { public and health } \\
\text { professionals (84) }\end{array}$ & Suicide prevention & $\begin{array}{l}\text { Assessing } \\
\text { suicide risk }\end{array}$ & $\begin{array}{l}\text { Participants in the } \\
\text { study }\end{array}$ \\
\hline $\begin{array}{l}\text { Brockington } \\
(2017)\end{array}$ & International & $\begin{array}{l}\text { Literature } \\
\text { review }\end{array}$ & Research articles (15) & $\begin{array}{l}\text { Suicide and filicide } \\
\text { in postpartum } \\
\text { psychosis }\end{array}$ & $\begin{array}{l}\text { Non-fatal } \\
\text { attempt(s) }\end{array}$ & $\begin{array}{l}\text { The participants' } \\
\text { contact with } \\
\text { physiotherapists } \\
\text { was assessed }\end{array}$ \\
\hline
\end{tabular}




\begin{tabular}{|c|c|c|c|c|c|c|}
\hline Study & Country & $\begin{array}{l}\text { Research } \\
\text { design }\end{array}$ & Sample $(n)$ & Focus of the study & $\begin{array}{c}\text { STBs } \\
\text { described }\end{array}$ & $\begin{array}{l}\text { Connection to } \\
\text { physiotherapists }\end{array}$ \\
\hline $\begin{array}{l}\text { Cottrell et al. } \\
(2017)\end{array}$ & Australia & Interviews & $\begin{array}{l}\text { Physiotherapists (15) } \\
\text { and other health } \\
\text { professionals (11) }\end{array}$ & $\begin{array}{l}\text { Perception of } \\
\text { telehealth in a } \\
\text { neurosurgical } \\
\text { and orthopaedic } \\
\text { physiotherapy } \\
\text { screening } \\
\text { clinic, and } \\
\text { multidisciplinary } \\
\text { service. }\end{array}$ & $\begin{array}{l}\text { Assessing } \\
\text { suicide risk }\end{array}$ & $\begin{array}{l}\text { Participants in the } \\
\text { study }\end{array}$ \\
\hline $\begin{array}{l}\text { Hickey et al. } \\
(2017)\end{array}$ & United States & Case study & $\begin{array}{l}\text { Patient with shoulder } \\
\text { pathology and was a } \\
\text { military sexual abuse } \\
\text { survivor (1) }\end{array}$ & $\begin{array}{l}\text { Patient-centred } \\
\text { perioperative } \\
\text { care plan }\end{array}$ & $\begin{array}{l}\text { Non-fatal } \\
\text { attempt(s) }\end{array}$ & $\begin{array}{c}\text { The patient had } \\
\text { participated in } \\
\text { physiotherapy }\end{array}$ \\
\hline $\begin{array}{l}\text { Miller et al. } \\
(2017)\end{array}$ & Canada & Case study & $\begin{array}{l}\text { Patients of a } \\
\text { chronic pain self- } \\
\text { management } \\
\text { programme (6) }\end{array}$ & $\begin{array}{l}\text { Patient responses } \\
\text { and changes } \\
\text { as a result of } \\
\text { programme } \\
\text { participation }\end{array}$ & Ideation & $\begin{array}{l}\text { The programme } \\
\text { was led by } \\
\text { physiotherapists }\end{array}$ \\
\hline $\begin{array}{l}\text { Sola and dos } \\
\text { Santos (2017) }\end{array}$ & Brazil & $\begin{array}{l}\text { Literature } \\
\text { review and } \\
\text { case study }\end{array}$ & $\begin{array}{l}\text { Patient with an } \\
\text { intrathoracic } \\
\text { dislocation (1) }\end{array}$ & $\begin{array}{l}\text { Intrathoracic } \\
\text { fracture- } \\
\text { dislocation of the } \\
\text { humerus }\end{array}$ & $\begin{array}{l}\text { Completed } \\
\text { suicide }\end{array}$ & $\begin{array}{c}\text { The patient had } \\
\text { participated in } \\
\text { physiotherapy }\end{array}$ \\
\hline $\begin{array}{l}\text { Omura and } \\
\text { Osorio (2018) }\end{array}$ & United States & Case study & $\begin{array}{l}\text { Patient with a traumatic } \\
\text { brain injury (1) }\end{array}$ & $\begin{array}{l}\text { Premenstrual } \\
\text { dysphoric } \\
\text { disorder }\end{array}$ & Ideation & $\begin{array}{c}\text { The patient had } \\
\text { participated in } \\
\text { physiotherapy }\end{array}$ \\
\hline $\begin{array}{l}\text { Dragesund and } \\
\text { Øien (2019) }\end{array}$ & Norway & Focus group & Physiotherapists (5) & $\begin{array}{l}\text { Norwegian } \\
\text { psychomotor } \\
\text { physiotherapy } \\
\text { for patients with } \\
\text { long-lasting } \\
\text { musculoskeletal } \\
\text { pain }\end{array}$ & $\begin{array}{l}\text { Client } \\
\text { ideation }\end{array}$ & $\begin{array}{l}\text { Participants in the } \\
\text { study }\end{array}$ \\
\hline $\begin{array}{l}\text { Tepper et al. } \\
(2019)\end{array}$ & United States & $\begin{array}{l}\text { Anecdotal } \\
\text { magazine } \\
\text { article } \\
\text { (not peer- } \\
\text { reviewed) }\end{array}$ & $\begin{array}{l}\text { Patient with chronic } \\
\text { back pain (1) }\end{array}$ & $\begin{array}{l}\text { Role of } \\
\text { physiotherapist } \\
\text { in the patient } \\
\text { recovery }\end{array}$ & $\begin{array}{l}\text { Non-fatal } \\
\text { attempt(s) }\end{array}$ & $\begin{array}{l}\text { The patient had } \\
\text { participated in } \\
\text { physiotherapy }\end{array}$ \\
\hline $\begin{array}{l}\text { Herdman et al. } \\
(2020)\end{array}$ & $\begin{array}{l}\text { United } \\
\text { Kingdom }\end{array}$ & Survey & $\begin{array}{l}\text { Patients of a hospital } \\
\text { outpatient neuro- } \\
\text { otology clinic (954) }\end{array}$ & $\begin{array}{l}\text { Feasibility of digital } \\
\text { mental health } \\
\text { screening }\end{array}$ & Ideation & $\begin{array}{r}\text { The clinic was staffed } \\
\text { by physiotherapists }\end{array}$ \\
\hline $\begin{array}{l}\text { McGrath et al. } \\
(2020)\end{array}$ & Australia & $\begin{array}{l}\text { Focus group } \\
\text { and } \\
\text { interviews }\end{array}$ & Physiotherapists (9) & $\begin{array}{l}\text { Experience of } \\
\text { physiotherapists } \\
\text { with clients with } \\
\text { STBS }\end{array}$ & $\begin{array}{l}\text { STBs and } \\
\text { assessing } \\
\text { suicide risk }\end{array}$ & $\begin{array}{l}\text { Participants in the } \\
\text { study }\end{array}$ \\
\hline
\end{tabular}

Note. STBs - Suicidal thoughts and behaviours. 
Contact between physiotherapist and clients with STBS Three studies provided data on the prevalence of STBs amongst people accessing physiotherapy services. Herdman et al. (2020) and Taylor et al. (2007) both found a point/one-month prevalence of STBs of $5.4 \%$ among physiotherapy clients, but through very different methods. Herdman et al. examined data from clients who experienced STBs and attended a hospital outpatient neuro-otology clinic over a one-year period in London, staffed by physiotherapists. In contrast, Taylor et al. drew on data from a representative sample of the general South Australian public. Comparatively, Kowal et al. (2014) found that $34.4 \%$ of participants reported suicidal ideation in a sample of 250 clients who participated in a group-based chronic pain management programme involving physiotherapists.

Although Taylor et al. (2007) drew on data from a representative sample of the general South Australian public $(n=5,037)$, only a small number of participants ( $n=249 ; 4.9 \%$ ) had consulted a physiotherapist in the four weeks before completing the survey. Consequently, the prevalence of physiotherapy clients experiencing STBs (5.4\%) was based on the people who had attended physiotherapy $(n=249)$. The number of participants attending the neuro-otology clinic in the study conducted by Herdman et al. was much larger than in Taylor et al. (954 and 249, respectively). However, the findings of Herdman et al. have limited generalisability, as only one clinic in a single hospital was studied. Kowal et al. (2014) examined clients with chronic pain; therefore, their findings may not be representative of clients of a generalist physiotherapy practice. Despite the limitations, based on these studies, it can be estimated that the point/month prevalence of STBs among physiotherapy clients is approximately $5 \%$ and that STB prevalence may be higher among certain client groups (e.g., those with chronic pain).

Several articles revealed valuable qualitative contextual information about the contact between physiotherapists and clients with STBS, such as the role of physiotherapy in case management and whether the physiotherapist engaged in discussions with the client about their STBs. McGrath et al. (2020) interviewed nine Australian physiotherapists working in private practice, who all reported contact with clients with STBs, including clients at immediate risk of suicide. Three studies described clients who had STBs and participated in physiotherapy treatment programmes. Gyllensten et al. (2003) interviewed clients who had undergone basic body awareness therapy, which was said to "restore balance, freedom and unity of body and mind ... [through] movements, breathing, massage and awareness" (Gyllensten et al., 2003, p. 173) in clients with mental illness. One client in the programme was transferred from the rehabilitation ward as a result of intense STBS (Gyllensten et al., 2003). Norwegian psychomotor physiotherapy (NPMP) is a physiotherapy approach targeting physical, psychological and social factors affecting the body through "muscle tension, breathing, posture, balance, movements and flexibility" (Dragesund \& Kvåle, 2016, p. 1). Of the 10 clients who underwent NPMP and were interviewed by Ekerholt (2011), two reported STBs (20\%). In contrast, Dragesund and Øien (2019) interviewed eight physiotherapists providing NPMP, one of which reported encountering a client they suspected may have been at risk of suicide.
Eleven case studies described physiotherapy contact with clients who had physical health conditions and had either made a suicide attempt (Brockington, 2017; Edmunds \& Gafner, 2003; Hickey et al., 2017; Lo Pardo et al., 2016; Marusic et al., 2014; Shetye et al., 2014), gone on to complete suicide (Sola \& dos Santos, 2017), or had suicidal ideation (Berg, 2011; Cheeks et al., 2014; Miller et al., 2017; Omura \& Osorio, 2018). Two of the case studies went beyond a brief mention of the involvement of a physiotherapist with a client with STBs. Brockington (2017) shared the story of a mother who completed filicide and attempted suicide after a letter from the "physiotherapist about a minor hip problem was interpreted [by the mother] as removing [the child] because of maltreatment" (Brockington, 2017, p. 67). Edmunds and Gafner (2003) reported that combining physiotherapy and psychological treatment improved the mood and well-being of a client with a history of physical and mental health issues, including a previous suicide attempt.

The literature in this area has also considered specific population groups, such as athletes and police. An editorial by Malcolm and Scott (2012) discussed the role of sports clinicians in the assessment and management of clients with STBs using the completed suicide of a German football player who hid his diagnosis of depression as an example. The footballer was reported to be very close with the club physiotherapist. Malcolm and Scott raised the question of how the footballer's fate may have been altered if the medical team had managed his condition differently. Berg et al. (2006) examined the helpseeking behaviours of Norwegian police officers. They found that $20.9 \%$ of police officers with suicidal ideation had contact with a physiotherapist in the preceding 12 months, suggesting that physiotherapists who work with police may encounter clients with STBS.

Four magazine/newspaper articles were identified that mentioned contact between physiotherapists and clients with STBs. Lascelles (2014), a suicide prevention lead nurse at Oxford Health NHS Foundation Trust, argued that physiotherapists need to be aware of their clients' risk of suicide. Lascelles referred to an unpublished survey conducted in 2013 aimed at mental health practitioners working in England. A small number of musculoskeletal physiotherapists $(n=5)$ responded to this unpublished survey, stating that they frequently encountered patients experiencing suicidal thoughts (K. Lascelles, personal correspondence, February 22, 2018). Based on these findings, Lascelles conducted SRA training for physiotherapists in the Oxford Health NHS Foundation Trust (Lascelles, 2014). One physiotherapist who participated in this training told Lascelles that she had a "high-risk individual on her caseload" and another stated "we [physiotherapists] all get clients who disclose suicidal thoughts or would be considered at risk of suicide" (Lascelles, 2014, p. 25).

Doesburg (2016), a professional advisor for Physiotherapy New Zealand, wrote an article to help guide physiotherapists in response to being contacted for guidance by "a few" (Doesburg, 2016, p. 8) private practice physiotherapists who had encountered clients with STBs. Doesburg provided a basic overview of SRA and mental health crisis management principles, such as the need to ask the client directly about their 
STBs, letting the client talk openly about their suicidal thoughts rather than changing the topic, and the need to refer these clients to mental health practitioners.

A member of the Agence France-Presse (2007) interviewed a physiotherapist working in a burns unit in Iraq, who reported that patients would often confide in her. The physiotherapist spoke about the issues of women completing and attempting suicide by self-burning; family conflicts and perceived issues associated with a male-dominated Iraqi society were reported to contribute to the phenomenon. The magazine article by Tepper et al. (2019) differed to previously mentioned newspaper/magazine articles as it explored the perspective of a physiotherapy client. The physiotherapy client told his story of how two spinal fractures, multiple spinal surgeries, and an opioid addiction resulted in him attempting to take his own life (Tepper et al., 2019). The person felt that the physiotherapist was instrumental in his recovery, stating: "She wasn't just my PT, but my psychologist, my sounding board, my marriage counselor [sic], educator of my options, and my kick in the ass" (Tepper et al., 2019, p. 38).

Physiotherapists" experiences of clients with STBs Six articles explicitly discussed a range of situations in which physiotherapists could encounter clients with STBs. A common finding was that physiotherapists self-reported a lack of skills to perform an effective SRA, due to a lack of training, guidance, and confidence.

McGrath et al. (2020) found that physiotherapists reported being relatively confident managing clients at high risk of suicide but lacked confidence in their ability to assess clients with less overt STBs. The authors referred to this finding as difficulty navigating the middle space, as it reflected the physiotherapists' lack of confidence managing clients in the middle portion of the suicide spectrum. The physiotherapists interviewed by McGrath et al. reported receiving little to no training on SRA. One physiotherapist in the study by Nielsen et al. (2014) similarly reported that most physiotherapists tended not to refer clients to mental health practitioners unless the client was "really sort of suicidal or in a really bad way" (Nielsen et al., 2014, p. 203). McVey et al. (2016) conducted two multi-professional structured discussion forums hosted on Twitter in 2014 and 2015 for a range of health practitioners, non-health professionals, and the general public to discuss suicide, and noted that some of the participating physiotherapists lacked the confidence to perform an SRA.

Again, a small number of participants, including at least one physiotherapist in the study by Cottrell et al. (2017), reported concern about their ability to manage clients with STBS. Cottrell et al. explored the perceptions of clinicians using the telehealth service delivery model, which might bring additional challenges to SRA that are not present in face-to-face consultations. Lascelles (2014) and Doesburg (2016) reported that physiotherapists had requested further training, advice, and direction on how to respond to clients with STBs. The findings presented in these articles demonstrate that physiotherapists were actively seeking support and guidance in their ability to manage clients experiencing STBs. One physiotherapist, who participated in the suicide awareness session delivered by
Lascelles (2014), reported increased understanding of the "less obvious risk issues" (p. 25), while another reported feeling more comfortable after the training knowing how to manage clients who disclose STBs.

The findings of the six articles that focused on physiotherapists experiences suggested reduced confidence in SRA skills due to a lack of specific training and that physiotherapists may only recognise the need for a referral to a mental health practitioner when a client is at high risk of suicide.

\section{DISCUSSION}

This narrative review revealed that despite the prevalence of STBs and evidence that poor physical health is a risk factor, there is a lack of international research that specifically investigated encounters between physiotherapists and clients with STBs. The level of evidence provided by the articles was generally low, but this was due to a lack of studies designed to empirically explore the phenomenon of interest. However, important anecdotal evidence was garnered, for example from case studies and magazine and newspaper articles, of the contact between physiotherapists and clients with STBS. Whilst the findings of these articles could not be systematically assessed, they provide lived experience narratives from physiotherapists and their clients experiencing STBs. In the context of the broader literature, which is relatively scarce, the findings also provide valuable insight that can inform a deeper understanding of potential issues and future research directions.

Based on the limited number of studies (Herdman et al., 2020; Taylor et al., 2007) which examined the point/month prevalence of STBs among physiotherapy clients, a tentative estimate of $5.4 \%$ can be made, which although not directly comparable, is higher than the 12-month prevalence of suicidal ideation in Australia, which is $2.4 \%$ among the general population (Australian Government Department of Health, 2009). Potter et al. (2003) found that $62 \%$ of physiotherapists see $41-80$ clients per week. Using the figures from three studies (Herdman et al., 2020; Potter et al., 2003; Taylor et al., 2007), it could be estimated that physiotherapists may encounter between two and five clients with STBs per week.

Physiotherapy clients with STBs included (a) people with physical conditions, (b) people with mental health issues, and (c) members of certain groups (such as police officers). Physiotherapists also came into contact with clients with STBS in several different settings, including general physiotherapy practice, hospital settings (e.g., psychiatric wards, orthopaedic outpatients, medical wards), sports settings, and specialist clinics (e.g., neuro-otology clinics).

Physiotherapists came into contact with people at various stages of the suicide trajectory. They encountered clients experiencing active suicidal ideation (e.g., McGrath et al., 2020), clients who went on to complete suicide (e.g., Sola \& dos Santos, 2017), and clients who previously attempted suicide (e.g., Tepper et al., 2019). Some physiotherapists were directly involved in the treatment of physical conditions that were a sequela of incomplete suicide (e.g., Lo Pardo et al., 2016), while other physiotherapists managed physical health conditions that were not associated with a suicide attempt (e.g., Hickey et al., 2017). 
Physiotherapists experience discomfort working with clients with STBs and lack confidence in performing an SRA (Cottrell et al., 2017; Doesburg, 2016; Lascelles, 2014; McGrath et al., 2020; McVey et al., 2016; Nielsen et al., 2014). Potter et al. (2003) found that clients who are unhappy in life, helpless/hopeless, catastrophisers, highly anxious, and negative thinkers, as well as clients who have low self-esteem/self-confidence or make significant self-disclosures, are generally considered "difficult patients" by physiotherapists. Based on the characteristics of "difficult patients", described by Australian physiotherapists in Potter et al., it is likely that clients with STBS may also be perceived as "difficult patients". Although the term "difficult patient" implies that the client is to blame, the term is more likely describing client encounters that are difficult for health practitioners to manage (Potter et al., 2003). Physiotherapists appeared to have the greatest difficulty assessing and managing clients at low to medium suicide risk, due to trouble identifying less overt STBs (McGrath et al., 2020). The authors hypothesise that physiotherapists may feel more confident managing clients at a high risk of suicide, as the need for a referral to a mental health clinician is more apparent. However, further research is needed to test this hypothesis.

\section{Limitations}

As the Framework for Suicide Risk Assessment and Management for NSW Health Staff (NSW Health, 2004) was the stimulus for the review, the research took an Australian orientation. International literature was included in the review after it became apparent during a preliminary literature search that there was a paucity of Australian literature. Australian literature formed a small component of this review $(n=4)$ and was not specific to NSW Health staff. Consequently, the relevance of the findings to the Framework for Suicide Risk Assessment and Management for NSW Health Staff (NSW Health, 2004) may be limited. Despite this, the findings of the review provide insight into the practices and preparedness of the international physiotherapy profession to manage clients with STBs. Another limitation of this review was that physiotherapists from multiple countries were discussed as one homogenous profession; this does not allow for a nuanced discussion of the differences in professional requirements and scope of practice that exist between countries. Limitations regarding the method include (a) the inclusion of articles that were anecdotal and not peerreviewed, (b) the influence of Google Scholar's non-transparent ranking algorithm on the identification of articles, and (c) the possibility of missing relevant articles as a consequence of limiting the review to the first 25 results of each Google Scholar search.

\section{Recommendations}

It is good practice for all physiotherapists to be able to identify and address STBs in clients. Future research into the inclusion of SRA content in entry-level physiotherapy courses is needed. Furthermore, physiotherapists working with populations at an elevated risk of suicide should receive post-graduate training to increase their confidence and competence for undertaking an SRA. It has been suggested that physiotherapists are wellpositioned to become leaders in the management of physical health of people with poor mental health (Andrew et al., 2019).
However, without basic competency in SRA, the well-being of clients and physiotherapists may be at risk.

Physiotherapists may consider seeking resources and further training in assessing and managing STBs from programmes such as Mental Health First Aid (MHFA). Edgar and Connaughton (2021) found that after MHFA training, physiotherapy students reported learning "that it is OK to ask directly if a person has thoughts of suiciding" (Edgar \& Connaughton, 2021, p. 191), which is consistent with evidence-based approaches to suicide management (Polihronis et al., 2020). However, El-Den et al. (2018) found that while pharmacy students who had completed MHFA training reported increased confidence in managing clients with STBs, simulated vignettes revealed that students often avoided using suicide specific terminology, with only half of students assessed as having passed the suicide vignette. Thus, although MHFA may improve knowledge and confidence, it may not be adequate alone to result in practice outcomes. It also should be noted that while health practitioners may complete MHFA, the programme is also aimed at the general public (DeFehr, 2016). Consequently, these programmes are not designed to be contextual to physiotherapy practice. The Framework for Suicide Risk Assessment and Management for NSW Health Staff (NSW Health, 2004) contains a general guide aimed at health practitioners on how to assess and manage a client with STBs and lists some of the important risk factors for suicide. However, it is also not contextual to physiotherapy practice.

Although guides may support physiotherapists to complete an SRA, perhaps suicide prevention should be embedded within physiotherapy practice and draw on existing strengths. For example, trust appears to be a prominent feature in physiotherapy practice and is said to be essential in the disclosure of STBs (Ganzini et al., 2013; Hiller, 2017). McGrath et al. (2020) found that physiotherapists appear to be "uncovering [STBs] through small talk, conversational-style interviewing, and a trusting practitioner-client relationship" (McGrath et al., 2020, p. 16). McGrath et al. also found that physiotherapists appear to be particularly interested in exploring how their clients are coping with their injury and daily life. One approach which may build on the existing strengths of physiotherapy is a coping planning approach to suicide prevention (Stallman, 2018). Coping planning is a suicide prevention strategy which shifts the focus from what the clinician does (completing an SRA) to what the client needs (healthy coping strategies; Stallman, 2018). Based on the findings of McGrath et al. (2020) and Hiller (2017), a coping planning approach appears well suited to the framework of physiotherapy practice and would likely build on existing strengths.

\section{CONCLUSION}

Although NSW Health (2004) identified physiotherapists as practitioners that need to be able to conduct a preliminary SRA, there is very little research that has investigated either the contact or experiences of physiotherapists with clients with STBs. Based on the articles identified in this study, it is evident that physiotherapists encounter clients with STBs in a range of clinical settings, and that physiotherapists believe 
they lack confidence and training to assess clients with STBs. This review highlights that physiotherapists may have the opportunity to contribute to suicide prevention due to their contact with clients at risk of suicide. If governments want to make suicide prevention everyone's business, they must ensure health practitioners working in all sectors, including private practice, are prepared and supported to manage clients with STBs. Future research is required to explore encounters between physiotherapists and clients with STBs in terms of the prevalence of STBs among physiotherapy clients, and whether physiotherapists are equipped to complete and action the outcomes of an SRA.

\section{KEY POINTS}

1. Physiotherapists may encounter clients with suicidal thoughts and behaviours due to the relationship between suicide and poor physical health and/or chronic pain.

2. There is substantial evidence of contact between physiotherapists and clients with STBs, but there is a paucity of research exploring the prevalence or frequency of this contact.

3. There is some evidence to suggest that physiotherapists lack confidence in performing an SRA.

4. Future research is needed to investigate encounters between physiotherapists and clients with STBs in the Australian context and the preparedness of physiotherapists to effectively manage these clients.

\section{DISCLOSURES}

No funding was obtained for this study. There are no conflicts of interest which may be perceived to interfere with or bias this study.

\section{PERMISSIONS}

No permissions were required.

\section{ACKNOWLEDGEMENTS}

We thank Dr Kylie Murphy for the support and guidance that she provided to the lead author.

\section{ADDRESS FOR CORRESPONDENCE}

Ryan L. McGrath, School of Community Health, Charles Sturt University, Albury, New South Wales, Australia; PO Box 789 Albury, New South Wales, 2640.

Email: ryanlachlanmcgrath@gmail.com

\section{REFERENCES}

Agence France-Presse. (2007, August 24). Self-immolation: The dark secret of Iraqi Kurdish women. The Daily Star. http://www.dailystar.com.lb/News/ Middle-East/2007/Aug-24/72516-self-immolation-the-dark-secret-of-iraqikurdish-women.ashx

Andrew, E., Briffa, K., Waters, F., Lee, S., \& Fary, R. (2019). Physiotherapists' views about providing physiotherapy services to people with severe and persistent mental illness: A mixed methods study. Journal of Physiotherapy, 65(4), 222-229. https://doi.org/10.1016/j.jphys.2019.08.001

Australian Government Department of Health. (2009). The mental health of Australians 2. https://www1.health.gov.au/internet/publications/ publishing.nsf/Content/mental-pubs-m-mhaust2-toc
Baethge, C., Goldbeck-Wood, S., \& Mertens, S. (2019). SANRA—a scale for the quality assessment of narrative review articles. Research Integrity and Peer Review, 4, 5. https://doi.org/10.1186/s41073-019-0064-8

Berg, A. M., Hem, E., Lau, B., \& Ekeberg, Ø. (2006). Help-seeking in the Norwegian police service. Journal of Occupational Health, 48(3), 145-153. https://doi.org/10.1539/joh.48.145

Berg, J. E. (2011). Electroconvulsive treatment of a patient with Parkinson's disease and moderate depression. Mental IIIness, 3(1), 8-10. https://doi. org/10.4081/mi.2011.e3

Brockington, I. (2017). Suicide and filicide in postpartum psychosis. Archives of Women's Mental Health, 20(1), 63-69. https://doi.org/10.1007/s00737016-0675-8

Calati, R., Laglaoui Bakhiyi, C., Artero, S., Ilgen, M., \& Courtet, P. (2015). The impact of physical pain on suicidal thoughts and behaviors: Meta-analyses. Journal of Psychiatric Research, 71, 16-32. https://doi.org/10.1016/j. jpsychires.2015.09.004

Cheeks, J. M., Ross, M. D., \& Sanko, J. P. (2014). Identification of a progressively worsening cardiac condition in a patient seen by a physical therapist: A case report. Cardiopulmonary Physical Therapy Journal, 25(4), 129-130. https://journals.Iww.com/cptj/pages/articleviewer.aspx?year=201 4\&issue $=12000$ \&article $=00042 \&$ type $=$ Fulltext

Clapperton, A., Bugeja, L., Newstead, S., \& Pirkis, J. (2020). Identifying typologies of persons who died by suicide: Characterizing suicide in Victoria, Australia. Archives of Suicide Research, 24(1), 18-33. https://doi. org/10.1080/13811118.2018.1507855

Clapperton, A., Newstead, S., Frew, C., Bugeja, L., \& Pirkis, J. (2020). Pathways to suicide among people with a diagnosed mental illness in Victoria, Australia. Crisis, 41(2), 105-113. https://doi.org/10.1027/02275910/a000611

Conejero, I., Olié, E., Courtet, P., \& Calati, R. (2018). Suicide in older adults: Current perspectives. Clinical Interventions in Aging, 13, 691-699. https:// doi.org/10.2147/CIA.S130670

Cottrell, M. A., Hill, A. J., O'Leary, S. P., Raymer, M. E., \& Russell, T. G. (2017). Service provider perceptions of telerehabilitation as an additional service delivery option within an Australian neurosurgical and orthopaedic physiotherapy screening clinic: A qualitative study. Musculoskeletal Science and Practice, 32, 7-16. https://doi.org/10.1016/j.msksp.2017.07.008

DeFehr, J. N. (2016). Inventing mental health first aid: The problem of psychocentrism. Studies in Social Justice, 10(1), 18-35. https://doi. org/10.26522/ssj.v10i1.1326

Dempsey, L. E., Karver, M. S., Labouliere, C., Zesiewicz, T. A., \& De Nadai, A. S. (2012). Self-perceived burden as a mediator of depression symptoms amongst individuals living with a movement disorder. Journal of Clinical Psychology, 68(10), 1149-1160. https://doi.org/10.1002/jclp.21901

Doesburg, S. (2016, November). Suicide intentions and self-harm - what advice should you provide? Physio Matters, 8-9. https://pnz.org.nz/Attach ment?Action=Download\&Attachment_id=1077

Dragesund, T., \& Kvåle, A. (2016). Study protocol for Norwegian psychomotor physiotherapy versus cognitive patient education in combination with active individualized physiotherapy in patients with long-lasting musculoskeletal pain - a randomized controlled trial. BMC Musculoskeletal Disorders, 17, 325. https://doi.org/10.1186/s12891-0161159-8

Dragesund, T., \& Øien, A. M. (2019). Demanding treatment processes in Norwegian psychomotor physiotherapy: From the physiotherapists' perspectives. Physiotherapy Theory and Practice, 35(9), 833-842. https:// doi.org/10.1080/09593985.2018.1463327

Edgar, S., \& Connaughton, J. (2021). Using mental health first aid training to improve the mental health literacy of physiotherapy students. Physiotherapy Canada, 73(2), 188-193. https://doi.org/10.3138/ptc-20190036

Edmunds, D., \& Gafner, G. (2003). Touching trauma: Combining hypnotic ego strengthening and zero balancing. Contemporary Hypnosis, 20(4), 215-220. https://doi.org/10.1002/ch.280 
Eisenberger, N. I. (2012). The neural bases of social pain: Evidence for shared representations with physical pain. Psychosomatic Medicine, 74(2), 126135. https://doi.org/10.1097/PSY.0b013e3182464dd1

Ekerholt, K. (2011). Awareness of breathing as a way to enhance the sense of coherence: Patients' experiences in psychomotor physiotherapy. Body, Movement and Dance in Psychotherapy, 6(2), 103-115. https://doi.org/10. 1080/17432979.2011.568762

El-Den, S., Chen, T. F., Moles, R. J., \& O'Reilly, C. (2018). Assessing mental health first aid skills using simulated patients. American Journal of Pharmaceutical Education, 82(2), 185-193. https://doi.org/10.5688/ ajpe6222

Fässberg, M. M., Cheung, G., Canetto, S. S., Erlangsen, A., Lapierre, S., Lindner, R., Draper, B., Gallo, J. J., Wong, C., Wu, J., Duberstein, P., \& Wærn, M. (2016). A systematic review of physical illness, functional disability, and suicidal behaviour among older adults. Aging \& Mental Health, 20(2), 166-194. https://doi.org/10.1080/13607863.2015.1083945

Fegg, M., Kraus, S., Graw, M., \& Bausewein, C. (2016). Physical compared to mental diseases as reasons for committing suicide: A retrospective study. BMC Palliative Care, 15, 14. https://doi.org/10.1186/s12904-016-0088-5

Ferrari, R. (2015). Writing narrative style literature reviews. Medical Writing, 24(4), 230-235. https://doi.org/10.1179/2047480615Z.000000000329

Fishbain, D. A., Bruns, D., Disorbio, J. M., \& Lewis, J. E. (2009). Risk for five forms of suicidality in acute pain patients and chronic pain patients vs pain-free community controls. Pain Medicine, 10(6), 1095-1105. https:// doi.org/10.1111/j.1526-4637.2009.00682.x

Froud, R., Patterson, S., Eldridge, S., Seale, C., Pincus, T., Rajendran D., Fossum, C., \& Underwood, M. (2014). A systematic review and meta-synthesis of the impact of low back pain on people's lives. BMC Musculoskeletal Disorders, 15(1), 50. https://doi.org/10.1186/1471-247415-50

Ganzini, L., Denneson, L. M., Press, N., Bair, M. J., Helmer, D. A., Poat, J., \& Dobscha, S. K. (2013). Trust is the basis for effective suicide risk screening and assessment in veterans. Journal of General Internal Medicine, 28(9), 1215-1221. https://doi.org/10.1007/s11606-013-2412-6

Gyllensten, A. L., Hansson, L., \& Ekdahl, C. (2003). Patient experiences of basic body awareness therapy and the relationship with the physiotherapist. Journal of Bodywork and Movement Therapies, 7(3), 173-183. https://doi.org/10.1016/\$1360-8592(02)00068-2

Haddaway, N. R., Collins, A. M., Coughlin, D., \& Kirk, S. (2015). The role of Google Scholar in evidence reviews and its applicability to grey literature searching. PLoS One, 10(9), e0138237. https://doi.org/10.1371/journal. pone.0138237

Herdman, D., Sharma, H., Simpson, A., \& Murdin, L. (2020). Integrating mental and physical health assessment in a neuro-otology clinic: Feasibility, acceptability, associations and prevalence of common mental health disorders. Clinical Medicine, 20(1), 61-66. https://doi.org/10.7861/ clinmed.2019-0156

Hickey, T. R., Kirwin, P. D., Gardner, E. C., \& Feinleib, J. (2017). Patientcentered perioperative care for a victim of military sexual trauma. Military Medicine, 182(5-6), e1807-e1811. https://doi.org/10.7205/ MILMED-D-16-00242

Hiller, A. J. M. (2017). Toward relationship-centred care: Patientphysiotherapist interaction in private practice [Doctoral thesis, University of Melbourne]. https://hdl.handle.net/11343/129510

Hiraiwa, T., Okada, H., Sawada, N., Nakayama, K., Senda, N., \& Kawanishi, M. (2014). Complex regional pain syndrome in a patient with acute drug poisoning: A case report. Chudoku Kenkyu, 27(4), 323-326.

Joiner, T. (2005). Why people die by suicide. Harvard University Press.

Klonsky, E. D., \& May, A. M. (2015). The three-step theory (3ST): A new theory of suicide rooted in the "ideation-to-action" framework. International Journal of Cognitive Therapy, 8(2), 114-129. https://doi. org/10.1521/ijct.2015.8.2.114
Kowal, J., Wilson, K. G., Henderson, P. R., \& McWilliams, L. A. (2014). Change in suicidal ideation after interdisciplinary treatment of chronic pain. The Clinical Journal of Pain, 30(6), 463-471. https://doi.org/10.1097/ AJP.0000000000000003

Lascelles, K. (2014, June 4). Suicide watch. Frontline, 20(10), 24-25. https:// www.csp.org.uk/system/files/frontline_magazine_4_june.pdf

LeRoy, A. S., Lu, Q., Zvolensky, M. J., Ramirez, J., \& Fagundes, C. P. (2018) Anxiety sensitivity moderates the painful effects of feeling burdensome to others. Cognitive Behaviour Therapy, 47(2), 126-138. https://doi.org/10.10 80/16506073.2017.1357749

Littlewood, D., Kyle, S. D., Pratt, D., Peters, S., \& Gooding, P. (2017) Examining the role of psychological factors in the relationship between sleep problems and suicide. Clinical Psychology Review, 54, 1-16. https:// doi.org/10.1016/j.cpr.2017.03.009

Lo Pardo, D., Amedola, D., Senatore, G., Damiano, A., Pezzuti, G., Pugliese, N., Locatelli, G., Siani, A., \& Vitola, N. M. (2016). Delayed neuropsychiatric syndrome after carbon monoxide poisoning: Inclusion of hyperbaric oxygen therapy in the recovery protocol. Emergency Care Journal, 12(1), 28-30. https://doi.org/10.4081/ecj.2016.5675

Malcolm, D., \& Scott, A. (2012). Suicide, sport and medicine [Editorial]. British Journal of Sports Medicine, 46(16), 1092. https://doi.org/10.1136/ bjsports-2012-090974

Marusic, S., Obreli Neto, P, R., Vuletic, V., \& Kirin, M. (2014). Peripheral mononeuropathy associated with valproic acid poisoning in an adult patient. International Journal of Clinical Pharmacology and Therapeutics, 52(9), 802-804. https://doi.org/10.5414/cp202074

McGrath, R. L., Parnell, T., Verdon, S., MacDonald, J. B., \& Smith, M. (2020). Trust, conversations and the 'middle space': A qualitative exploration of the experiences of physiotherapists with clients with suicidal thoughts and behaviours. PLoS One, 15(9), e0238884. https://doi.org/10.1371/journal. pone.0238884

McRae, M., \& Hancock, M. J. (2017). Adults attending private physiotherapy practices seek diagnosis, pain relief, improved function, education and prevention: A survey. Journal of Physiotherapy, 63(4), 250-256. https://doi. org/10.1016/j.jphys.2017.08.002

McVey, N., Fillingham, J., \& Owen, H. (2016). Suicide prevention: A planned approach to discussing a sensitive topic through tweetchats. Physiotherapy, 102(Suppl. 1), e131-e132. https://doi.org/10.1016/j. physio.2016.10.148

Miller, J., MacDermid, J. C., Richardson, J., Walton, D. M., \& Gross, A. (2017) Depicting individual responses to physical therapist led chronic pain selfmanagement support with pain science education and exercise in primary health care: Multiple case studies. Archives of Physiotherapy, 7, 4. https:// doi.org/10.1186/s40945-017-0032-x

New South Wales Department of Health. (2004). Framework for suicide risk assessment and management for NSW Health staff. https://www.health. nsw.gov.au/mentalhealth/resources/Publications/suicide-risk.pdf

New South Wales Department of Health. (2019). Annual report 2018-19. https://www.health.nsw.gov.au/annualreport/Publications/2019/preface. pdf

Nielsen, M., Keefe, F. J., Bennell, K., \& Jull, G. A. (2014). Physical therapistdelivered cognitive-behavioral therapy: A qualitative study of physical therapists' perceptions and experiences. Physical Therapy, 94(2), 197-209. https://doi.org/10.2522/ptj.20130047

Omura, J., \& Osorio, M. (2018). Premenstrual dysphoric disorder in a patient with traumatic brain injury: A case presentation. $P M \& R, 10(3), 317-319$. https://doi.org/10.1016/j.pmrj.2017.07.080

Ortega, J. L. (2014). Google Scholar: On the shoulders of a giant. In J. L. Ortega (Ed.), Academic Search Engines (pp. 109-141). Chandos Publishing. https://doi.org/10.1533/9781780634722.109

Pachkowski, M., Hewitt, P. L., \& Klonsky, E. D. (2020, April 22-25). The unique contributions of physical pain and psychological pain to suicidal desire. [Poster presentation]. American Association of 
Suicidology, Virtual Conference. https://static1.squarespace.com/ static/5da0c00e809d9e754ead15f5/t/5ea19d820b77487bad 1e6815/1587649926155/The+Unique+Contributions+of+Physical+Pain+a nd+Psychological+Pain+to+Suicidal+Desire-01.pdf

Papadakis, S. A., Galanakos, S., Apostolaki, K., Kateros, K., Antoniadou, O., Macheras, G., \& Sapkas, G. (2014). Spinal cord injuries following suicide attempts. In Y. Dionyssiotis (Ed.), Topics in paraplegia (pp. 53-70). InTech. https://doi.org/10.5772/56986

Papadakis, S. A., Pallis, D., Galanakos, S., Georgiou, D. F., Kateros, K., Macheras, G., \& Sapkas, G. (2020). Falls from height due to accident and suicide attempt in Greece. A comparison of the injury patterns. Injury, 51(2), 230-234. https://doi.org/10.1016/j.injury.2019.12.029

Paré, G., \& Kitsiou, S. (2017). Methods for literature reviews. In F. Lau \& C. Kuziemsky (Eds.), Handbook of ehealth evaluation: An evidence-based approach (pp. 157-180). University of Victoria. https://www.ncbi.nlm.nih gov/books/NBK481590/pdf/Bookshelf_NBK481590.pdf

Paré, G., Trudel, M.-C., Jaana, M., \& Kitsiou, S. (2015). Synthesizing information systems knowledge: A typology of literature reviews. Information \& Management, 52(2), 183-199. https://doi.org/10.1016/j. im.2014.08.008

Petrosky, E., Harpaz, R., Fowler, K. A., Bohm, M. K., Helmick, C. G., Yuan, K., \& Betz, C. J. (2018). Chronic pain among suicide decedents, 2003 to 2014: Findings from the national violent death reporting system. Annals of Internal Medicine, 169(7), 448-455. https://doi.org/10.7326/M18-0830

Polihronis, C., Cloutier, P., Kaur, J., Skinner, R., \& Cappelli, M. (2020). What's the harm in asking? A systematic review and meta-analysis on the risks of asking about suicide-related behaviors and self-harm with quality appraisal. Archives of Suicide Research. Advance online publication. https://doi.org/10.1080/13811118.2020.1793857

Potter, M., Gordon, S., \& Hamer, P. (2003). The difficult patient in private practice physiotherapy: A qualitative study. Australian Journal of Physiotherapy, 49(1), 53-61. https://doi.org/10.1016/S00049514(14)60188-4
Rovira, C., Codina, L., Guerrero-Solé, F., \& Lopezosa, C. (2019). Ranking by relevance and citation counts, a comparative study: Google Scholar, Microsoft Academic, WoS and Scopus. Future Internet, 11(9), 202. https:// doi.org/10.3390/fi11090202

Shetye, J. V., Surkar, S. M., Karnik, N. D., \& Mehta, A. A. (2014). Delayed onset neuropathy along with recurrent laryngeal nerve palsy due to organophosphate poisoning and the role of physiotherapy rehabilitation. Indian Journal of Critical Care Medicine, 18(2), 102-104. https://doi. org/10.4103/0972-5229.126082

Sola Jr, W. C., \& dos Santos, P. S. (2017). Intrathoracic fracture-dislocation of the humerus - case report and literature review. Revista Brasileira de Ortopedia, 52(2), 215-219. https://doi.org/10.1016/j.rboe.2017.01.005

Stallman, H. M. (2018). Coping planning: A patient-centred and strengthsfocused approach to suicide prevention training. Australasian Psychiatry, 26(2), 141-144. https://doi.org/10.1177/1039856217732471

Tang, N. K., \& Crane, C. (2006). Suicidality in chronic pain: A review of the prevalence, risk factors and psychological links. Psychological Medicine, 36(5), 575-586. https://doi.org/10.1017/s0033291705006859

Taylor, A., Dal Grande, E., Gill, T., Fisher, L., \& Goldney, R. (2007). Detecting determinants of suicidal ideation: South Australian surveillance system results. International Journal of Public Health, 52(3), 142-152. https://doi. org/10.1007/s00038-007-5064-7

Tepper, D. E., Ries, E., \& Elliott, T. (Eds.). (2019, September 1). Opening event: A moving account of a journey out of pain and addiction. PT in Motion, 11(8), 38. https://www.apta.org/contentassets/ af0e64b4817a491f8cabe6ccb159ebec/ptinmotionseptember2019.pdf

World Health Organization. (2010). Towards evidence-based suicide prevention programmes. https://apps.who.int/iris/handle/10665/207049 